\title{
Considerații referitoare la cartografierea antroponimelor și toponimelor românești ${ }^{\dagger}$
}

\author{
Ionel Boamfă* \\ Facultatea de Geografie și Geologie, Universitatea "Alexandru Ioan Cuza", Bd. Carol I 11, 700506 Iaşi, România
}

\author{
Despre articol \\ Istoric: \\ Primit 19 iulie 2018 \\ Acceptat 26 august 2018 \\ Publicat 7 octombrie 2018 \\ Cuvinte-cheie: \\ toponim \\ antroponim \\ cartografiere \\ spațiul românesc
}

\begin{abstract}
Rezumat
Articolul încearcă să evidențieze unele aspecte referitoare la cartografierea toponimelor şi antroponimelor, atît în spațiul românesc, cît și la un nivel mai larg (european, mondial). În cazul toponimelor, este evidențiată răspîndirea oiconimelor cu sufixele -ești, -eni/-ani, -ari, -ovți/-evți, -inți în spațiul românesc. Acest spațiu include teritoriul actual al României și Republicii Moldova și acele regiuni din Ucraina, Bulgaria și Ungaria ce au aparţinut, temporar, statului român. Sufixele românești -ești, -eni/-ani, -ari apar cel mai frecvent, cea mai mare prezență înregistrînd-o primul sufix. Pentru cartografierea antroponimelor, ne-am oprit, deocamdată, la cartografierea răspîndirii numelor care au sufixul - escu, la nivel mondial, pe state. Se constată că acest sufix apare cel mai frecvent în România și/sau Republica Moldova.
\end{abstract}

\section{Introducere}

Ne propunem să evidențiem cîteva chestiuni legate de cartografierea antroponimelor și toponimelor, indiferent de scara de analiză utilizată. Printre acestea se numără alegerea unui decupaj administrativ „unitar”, dese $(\mathrm{m})$ nat convențional, indiferent de epocile / perioadele / intervalele analizate (pentru comparabilitatea datelor), faptul că, chiar dacă nu avem acces la întreaga informaţie antroponimică pentru anumite intervale, dacă înainte și după un interval cu prezență atestată sub medie avem informații care probează frecvența peste medie a numelui, este posibil ca acesta să fie atestat și în intervalul în cauză peste medie (avînd, în asemenea situații, fie acces incomplet la informaţia antroponimică, fie fiind vorba de date incomplet publicate), etc. Pentru spaţiul românesc, la care ne vom referi în mod special, vom utilizastrict convențional, pentru comparabilitatea datelor, atît spațială, cît și temporală —un fond de hartă la nivel comunal, ce include actualele comune existente în decupajul administrativ al României, Republicii Moldova și al teritoriilor aflate azi în componența Ungariei, Bulgariei și Ucrainei ce au aparținut statului român.

\section{Metodologie de cercetare. Probleme}

În realizarea acestui demers am utilizat o serie de metode grupate în două categorii: metode de colectare a datelor, respectiv, de analiză și interpretare a acestor date. Dintre metodele de colectare (sursele de documentare), am utilizat indicatoarele de localități, recensămintele populației, hărțile topograficepentru inventarierea informației toponimice (a numelor de localități) 一, iar, în ceea ce privește colectarea numelor de familie românești, la nivel mondial, site-ul forebears.io ${ }^{1}$.

\footnotetext{
${ }^{\dagger} \mathrm{O}$ versiune anterioară a acestui text a fost prezentată sub formă de comunicare la simpozionul „Toponimia între istorie, geografie și lingvistică”, Iași, 10 mai 2018.

*Adresă de corespondență: ionel_boamfa@yahoo.com.

${ }^{1}$ La introducerea în calculator a datelor cuprinzînd numărul de purtători ai numelor analizate, au contribuit și studenții promoțiilor 2017 și 2018, de la specializările Geografia Turismului și Geografia Turismului - Filieră Francofonă, din cadrul Facultății de Geografie și Geologie a Universității „Alexandru Ioan Cuza” din Iași.
} 
Ionel Boamfă

Ca metode de analiză și interpretare am utilizat metoda statistică, cu ajutorul căreia datele introduse în calculator, într-un fișier Microsoft Excel, au fost prelucrate, fie spre a fi aduse în format procentual, fie pentru calcularea coeficientului de distribuție spațială ${ }^{2}$. Apoi, am utilizat metoda cartografică pentru realizarea hărților, folosind programul Philcarto. Hărțile au fost realizate în plaje de culori, fie utilizînd datele procentuale, fie cele calculate pentru coeficientul de distribuție spațială. Hărțile au fost prelucrate $\mathrm{cu}$ ajutorul programului Adobe Illustrator.

Pe parcursul activității am avut de surmontat cîteva probleme. Prima se leagă de informațiile privind numele de localități. O parte dintre acestea (în România, de pildă) sînt creații oficiale ale administraţiei românești (mai ales în Transilvania). Aceasta a presupus verificarea formei inițiale a numelui, iar dacă numele actual, conținînd unul din sufixele analizate, are caracter oficial, acesta nu a fost inclus în analiză.

Apoi, pentru reprezentarea datelor, ne-am lovit de inexistența unui fond de hartă la nivel comunal, pentru întregul spațiu românesc. Pornind de la fondul de hartă la nivel comunal al României (care a trebuit şi el actualizat), la care am alăturat și fondul de hartă la acelaşi nivel al Republicii Moldova, am desenat conturul tuturor celorlalte unităţi administrative de același nivel, din Ungaria, Bulgaria și Ucraina (Fig. 1).

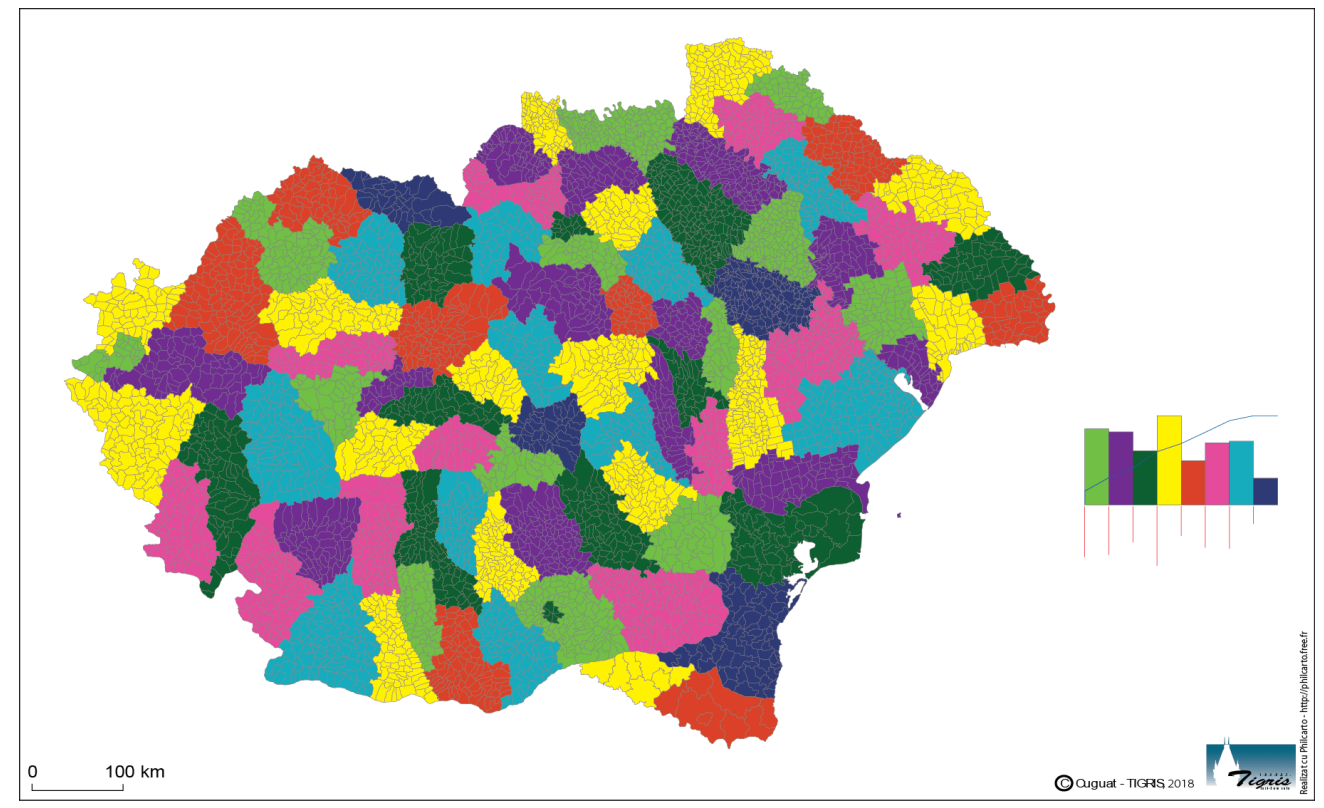

Figura 1: România - fond de hartă sintetic la nivel comunal.

În fine, am utilizat datele pentru numele de familie de pe site-ul forebears.io pentru Regatul Unit al Marii Britanii și Irlandei de Nord, care sînt (re)prezentate la nivelul entităţilor administrative constitutiveAnglia, Țara Galilor, Scoția și Irlanda de Nord. În consecință, aceste date au fost însumate la nivelul întregului Regat.

\section{Reprezentarea cartografică a toponimelor și a antroponimelor}

Pentru reprezentarea cartografică a diferitelor elemente onomastice (toponime, antroponime) ne vom referi mai întîi la reprezentarea numelor de localități (oiconimelor). Ne-am oprit, deocamdată, doar asupra acelora care se referă la dezvoltarea respectivelor localități din comunități patriarhale de țărani liberi

\footnotetext{
${ }^{2}$ Acest coeficient rezultă din împărțirea procentului de purtători ai unui/unor nume într-o entitate administrativă (comună, județ, regiune, țară, etc.) la procentul deținut de populația aceleiași entităţi. La nivelul zonei analizate, valoarea coeficientului este 1 (egală cu procentul de $100 \%$ al purtătorilor numelor, dat de suma procentelor tuturor entităţilor administrative, împărțit la 100\%, suma procentelor populației acelorași entități). În consecință, se întîlnesc, teoretic, trei situații: a) în care coeficientul de distribuție spațială este mai mare decît 1 , ceea ce înseamnă că numele este suprareprezentat, în raport cu media; b) acest coeficient este mai mic decît 1 , aceasta însemnînd că acel nume este subreprezentat, prin raport cu media, și c) coeficient egal cu 1, situație pe care, încă, nu am consemnat-o.
} 
(obști țărănești), proces marcat, din punct de vedere onomastic, de utilizarea unor sufixe caracteristice, fie românești (-ești, -eni/-ani, -ari), fie slave (-ovți/-evți, -inți) (vezi Ungureanu, 2006, p. 68, 130 și Moldovanu, 1970, p. 19).

O analiză cuprinzătoare a legilor de formare a acestora a fost realizată de Dragoș Moldovanu (1970). De asemenea, Tezaurul Toponimic al României. Moldova, volumul II, partea I (2014), cuprinde un bogat indice toponimic, cu trimitere la aceleași elemente oiconimice. Noi ne vom fixa atenția asupra repartiției spațiale a acestora, deocamdată, doar în ceea ce privește distribuția geografică a numelor de așezări actuale, urmînd ca, în perspectivă, să le analizăm și pe cele dispărute.

Astfel, în harta de mai jos, am reprezentat, pe baza datelor procentuale, distribuția tuturor numelor de localități care au unul dintre aceste sufixe $e^{3}$. În prima hartă, aceste informații au fost reprezentate la nivel județean (Fig. 2). Este un nivel mai general, dar care oferă avantajul de a surprinde continuitățile sau discontinuităţile spațiale ale repartiţiei unui obiect, proces sau fenomen. Astfel, din cele 18280 de localități din spațiul românesc, aproape 4000 (3934, adică 21,5\%) au în componența numelui un asemenea sufix. Cele mai compacte concentrări se observă în județele Moldovei, de ambele părți ale Prutului, în special în părțile centrală și nordică. În sudul țării, asemenea concentrări se remarcă mai ales în județele situate în apropierea Carpaților Meridionali, în vestul Munteniei și în Oltenia. Urmare a unei evoluții istorice care a legat aceste ținuturi, mult timp, de influențe străine-ungare sau/și (austro-) ungare-, Transilvania are o frecvență mai redusă a unor asemenea oiconime, deși, izolat, există arii cu o prezență însemnată a acestora—zona Munților Apuseni.

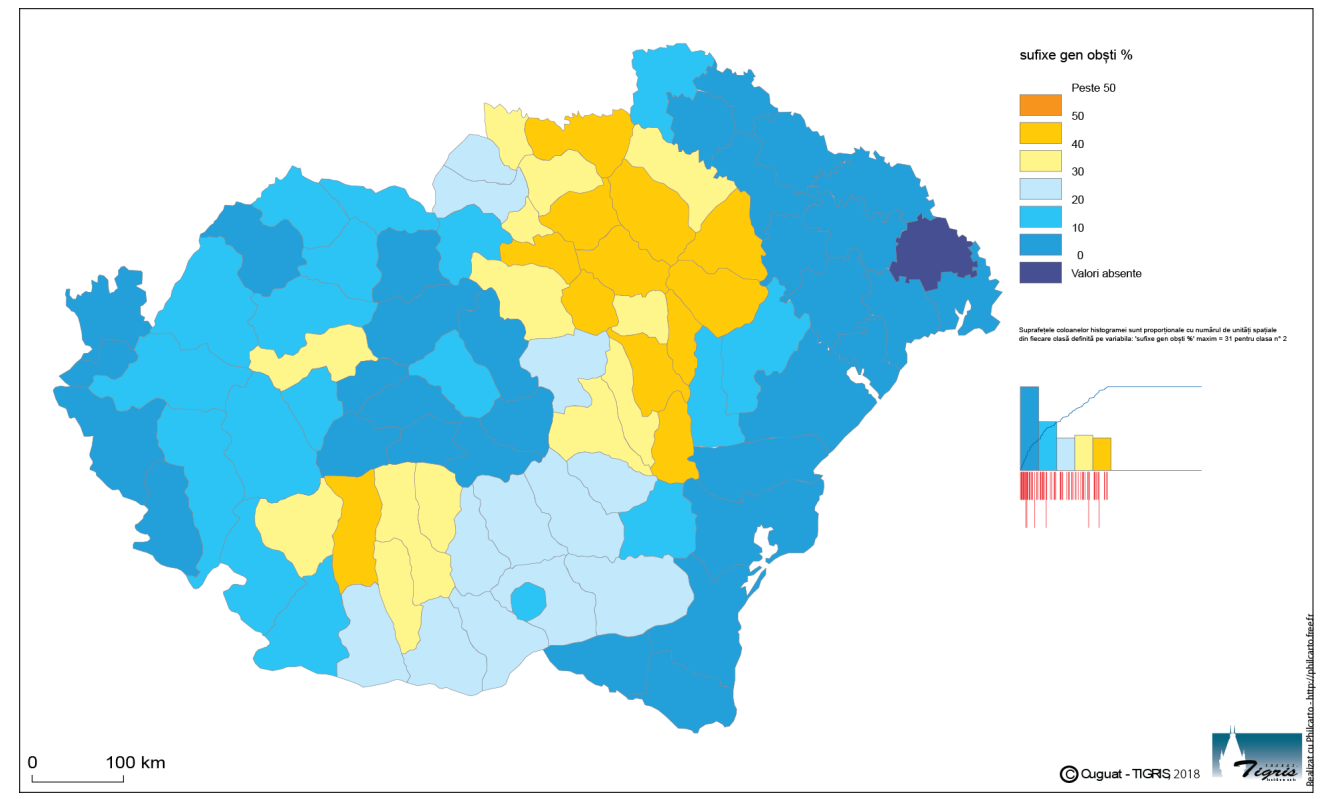

Figura 2: Distribuția oiconimelor cu sufixe ce arată dezvoltarea localităților din comunități de țărani liberi (-ești, -eni/-ani, -ari, -ovțil-evți, -inți) în spațiul românesc la nivel județean.

Dacă detaliem nivelul de (re)prezentare la cel comunal, situaţia nu se schimbă esenţial, deși acest nivel prezintă avantajele detaliilor mai bine evidențiate. Din nou, concentrările cele mai însemnate ale acestor sufixe se regăsesc în Moldova centralăși nordică, și la est și la vest de Prut, și în zonele montane, subcarpatice și de podiş ale Munteniei și Olteniei. De această dată, însă, detaliile evidențiază peste Carpați mai multe arii-nu foarte extinse, dar destul de numeroase-cu prezența unor asemenea oiconime. Pe lîngă aria Apusenilor, se remarcă Banatul Montan, Maramureșul, sudul Ardealului, etc. (Fig. 3).

Putem detalia analiza mai întîi cu referire la contextul etnic-românesc sau slav-ce a imprimat sufixarea. Astfel, numele cu sufixe românești (-ești, -enil-ani sau -ari) reprezintă majoritatea covîrșitoare

${ }^{3}$ Calcularea acestor procente s-a făcut prin împărțirea numărului de localități al căror nume conține asemenea sufixe la numărul total de așezări al fiecărei comune. 
a acestor oiconime: 3694 (20,2\%), față de doar 240, care au sufixe slave. În ceea ce privește repartiția lor spațială, aceasta este, în linii mari, aproape identică cu cea cuprinzînd ansamblul tuturor oiconimelor cu astfel de sufixe (Fig. 4).

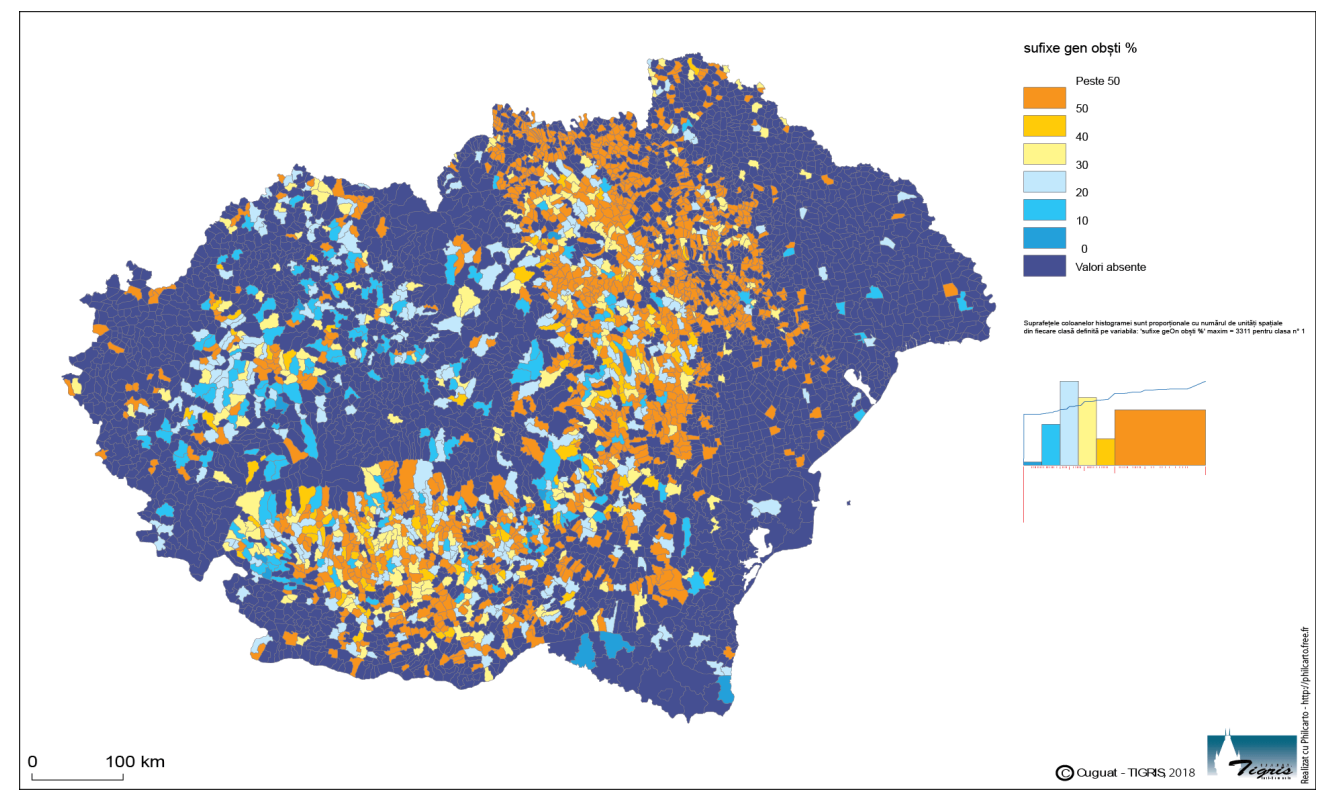

Figura 3: Distribuția oiconimelor cu sufixe ce arată dezvoltarea localităților din comunități de țărani liberi (-ești, -eni/-ani, -ari, -ovți/-evți, -inți) în spațiul românesc la nivel comunal.

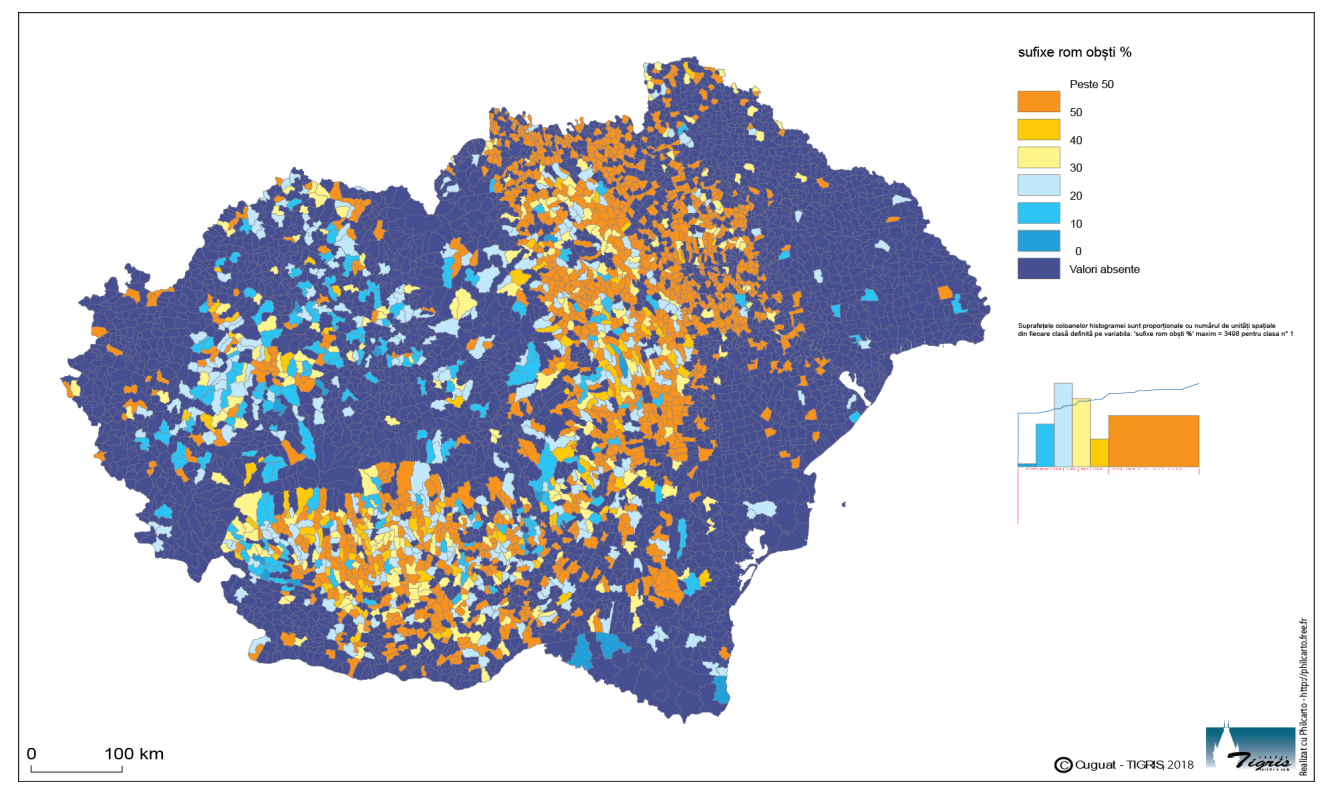

Figura 4: Distribuția oiconimelor cu sufixe românești ce arată dezvoltarea localităților din comunități de țărani liberi (-ești, -eni/-ani, -ari) în spațiul românesc la nivel comunal.

Toponimele cu sufixe de origine slavă, au un procent modest (doar 1,3\%). Repartiția spațială se limitează doar la extremitatea nordică a spațiului românesc (nordul Bucovinei și al Basarabiei), cu o prezență izolată în restul țării (în sudul Moldovei, Banat sau Maramureș)—Fig. 5.

Putem vorbi, pe scurt, de fiecare dintre aceste sufixe. Astfel, din cele peste $20 \%$ nume cu sufixe românești, cel mai bine reprezentat-13,1\% (2403 așezări) - este sufixul -ești. Probabil vechimea sa foarte mare-este considerat de origine latină, sau chiar traco-dacică-explică frecvența cea mai mare pe care acesta o are la nivelul oiconimelor referitoare la vechile obști țăănești. Fără a avea pretenția că vom 
clarifica lucrurile, opinăm—pe baza unei serii destul de numeroase de oiconime înregistrate în antichitate în spațiul carpato-balcanic locuit de traco-daci (ulterior romanizați, în mare parte și deveniți români)—că există sufixiente temeiuri spre a lua în considerare ipoteza originii trace a sufixului -ești, derivat dintr-un -isk. Asemenea toponime au o extensiune considerabilă, din Ungaria și Croația pînă în sudul Peninsulei Balcanice, nelipsind nici din ținuturile nord-dunărene, unde apar în Banat, Muntenia și sudul Basarabiei.

Mai mult, acelaşi sufix -isc/-isk era întrebuințat și la crearea unor antroponime la tracii intrați deja în procesul de romanizare, în secolele III-VI d. $\mathrm{Hr}$ (Fig. 6). Astfel, amintim existența mai multor locuitoriepiscopi și chiar împărați romani (de origine tracică) — ce purtau numele Basiliscus, un derivat de la Basilius $^{4}$.

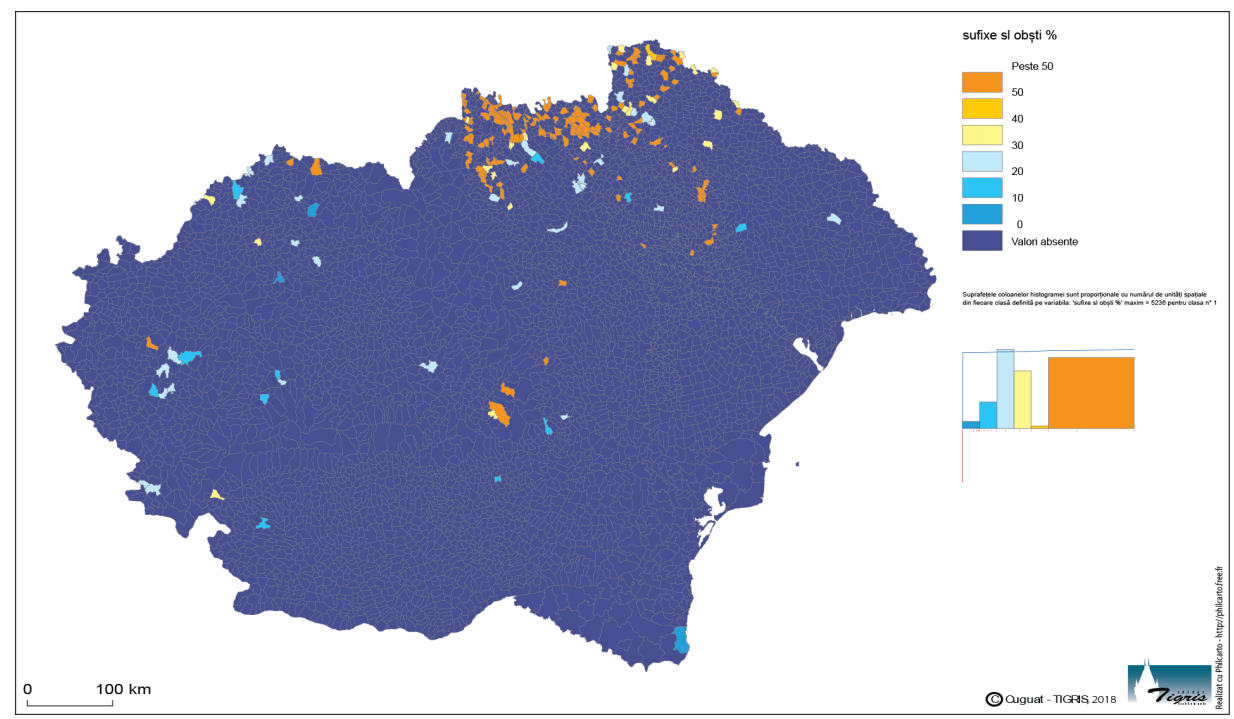

Figura 5: Distribuția oiconimelor cu sufixe slave ce arată dezvoltarea localităților din comunități de țărani liberi (-ovți/-evți, -inți) în spațiul românesc la nivel comunal.

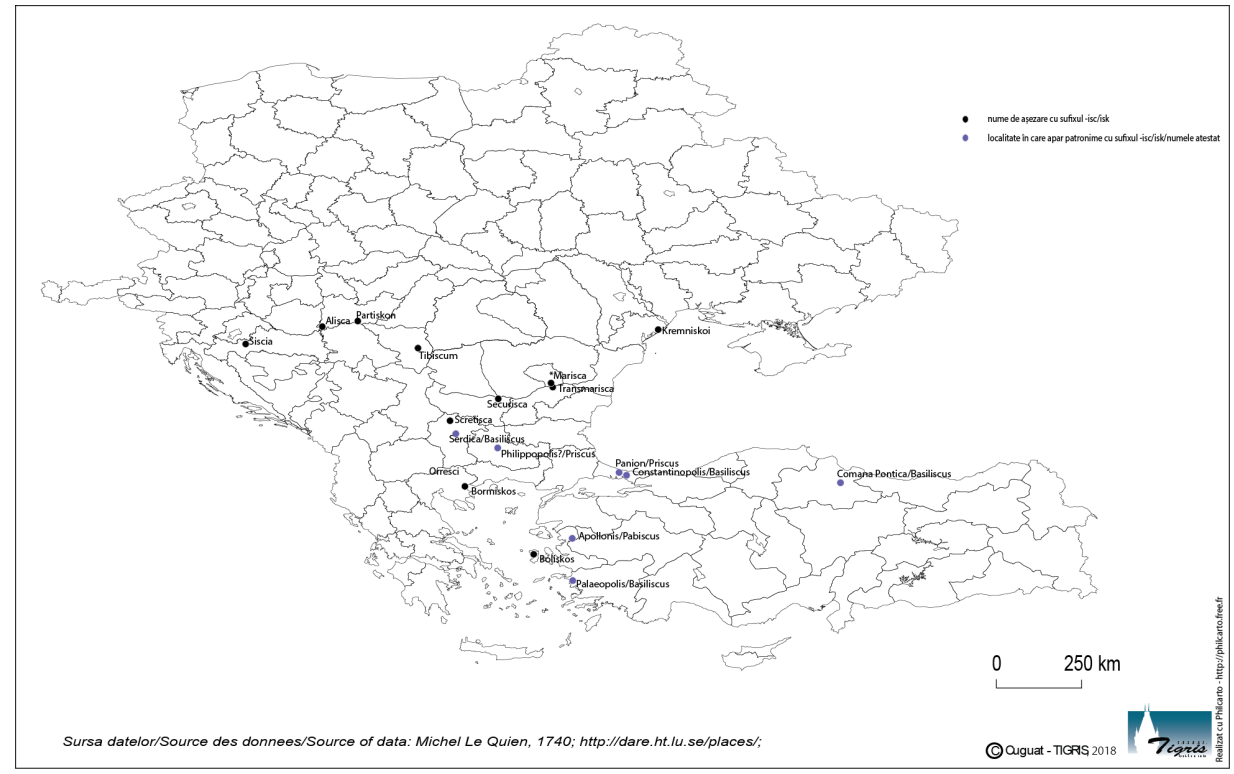

Figura 6: Distribuția toponimelor și antroponimelor cu sufixul -isc/-isk în spațiul carpato-balcanic.

\footnotetext{
${ }^{4}$ Astfel, dacă, în română, Basilius a evoluat spre Vasile, Basiliscus ar putea fi „strămoșul” lui Vasilescu. O dovadă a utilizării, de către traco-romani, a numelui Basiliscus este mențiunea că un asemenea purtător al numelui, ajuns împărat roman, era fiul împăratului Leo I Tracul.
} 
Ionel Boamfă

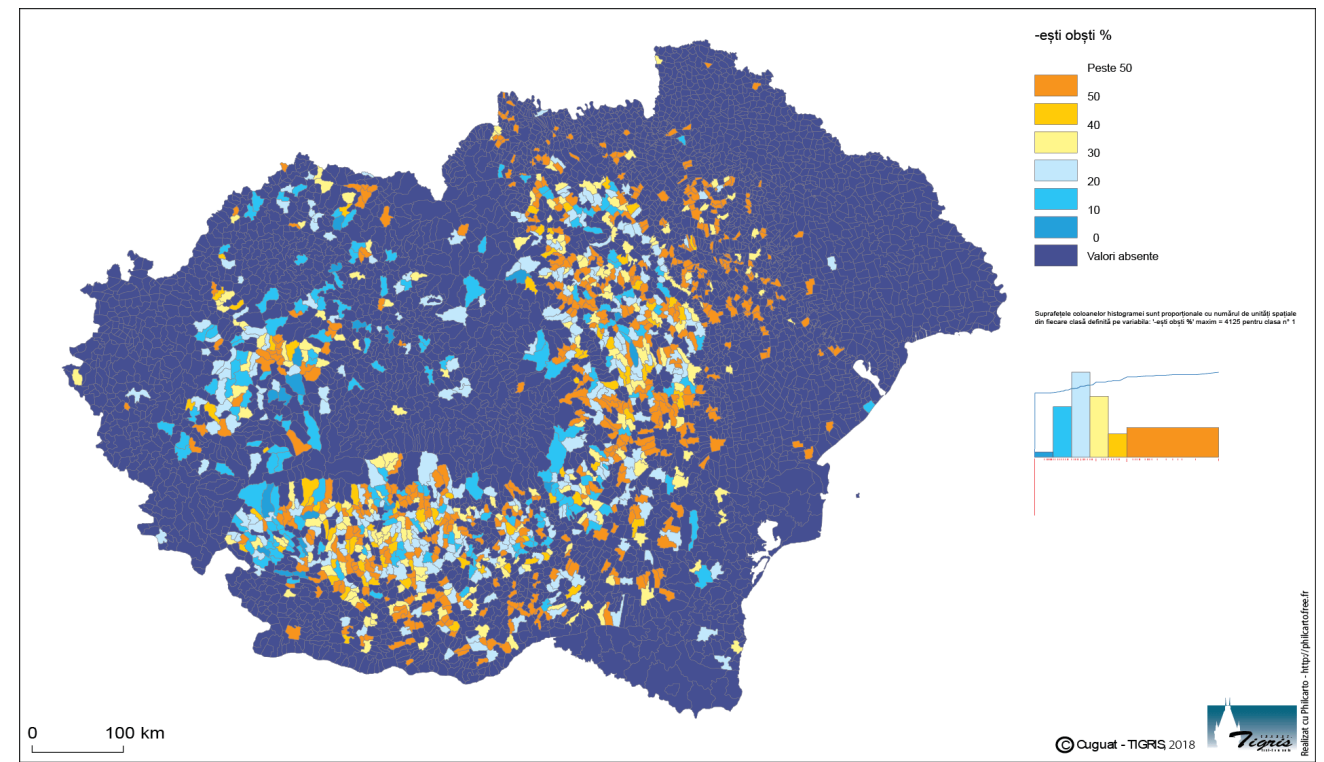

Figura 7: Distribuția oiconimelor cu sufixul -ești ce arată dezvoltarea localităţilor din comunități de țărani liberi în spațiul românesc la nivel comunal.

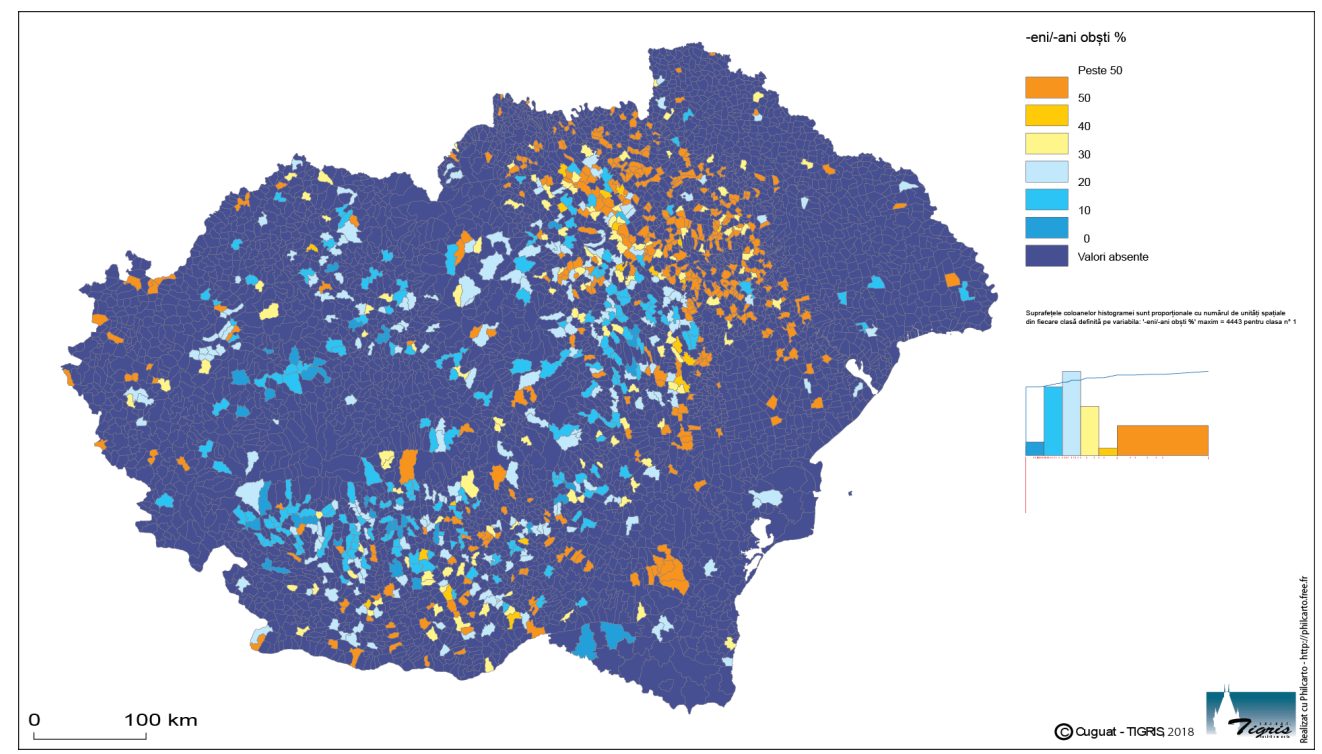

Figura 8: Distribuția oiconimelor cu sufixele -eni/-anice arată dezvoltarea localităților din comunități de țărani liberi în spațiul românesc la nivel comunal.

În prezent, răspîndirea geografică a oiconimelor cu acest sufix evidențiază aceleași zone, în toate cele trei mari provincii istorice românești: Moldova, Țara Românească și Transilvania (Fig. 7).

În schimb, dacă ne referim la sufixele -eni/-ani, numărul și ponderea lor sînt ceva mai modeste: 675 localităţi (3,7\%) Acestea apar mai frecvent în Moldova, în lungul Prutului şi mai cu seamă la est de acest rîu. Chiar dacă astfel de nume nu lipsesc din celelalte regiuni, frecvența lor este mult mai modestă, așa cum se observă în Fig. 8.

Mult mai rar este sufixul -ari, cu rol social. Sînt doar 26 de asemenea oiconime (0,14\%), localizate, izolat, în nordul și sud-vestul Moldovei și în Banat (Fig. 9).

Dintre sufixele slave, cel mai frecvent utilizate sînt -ovți/-evți. Acestea se regăsesc în componența numelui a 180 de aşezări (circa 1\%), concentrate, destul de compact, în Bucovina și nordul Basarabiei, unde coboară și în lungul Nistrului, dar și în Transnistria (mai ales în partea sa nordică). Alte arii izolate se regăsesc în sud-vestul Moldovei, în sud-estul și nord-vestul Transilvaniei (Fig. 10). 


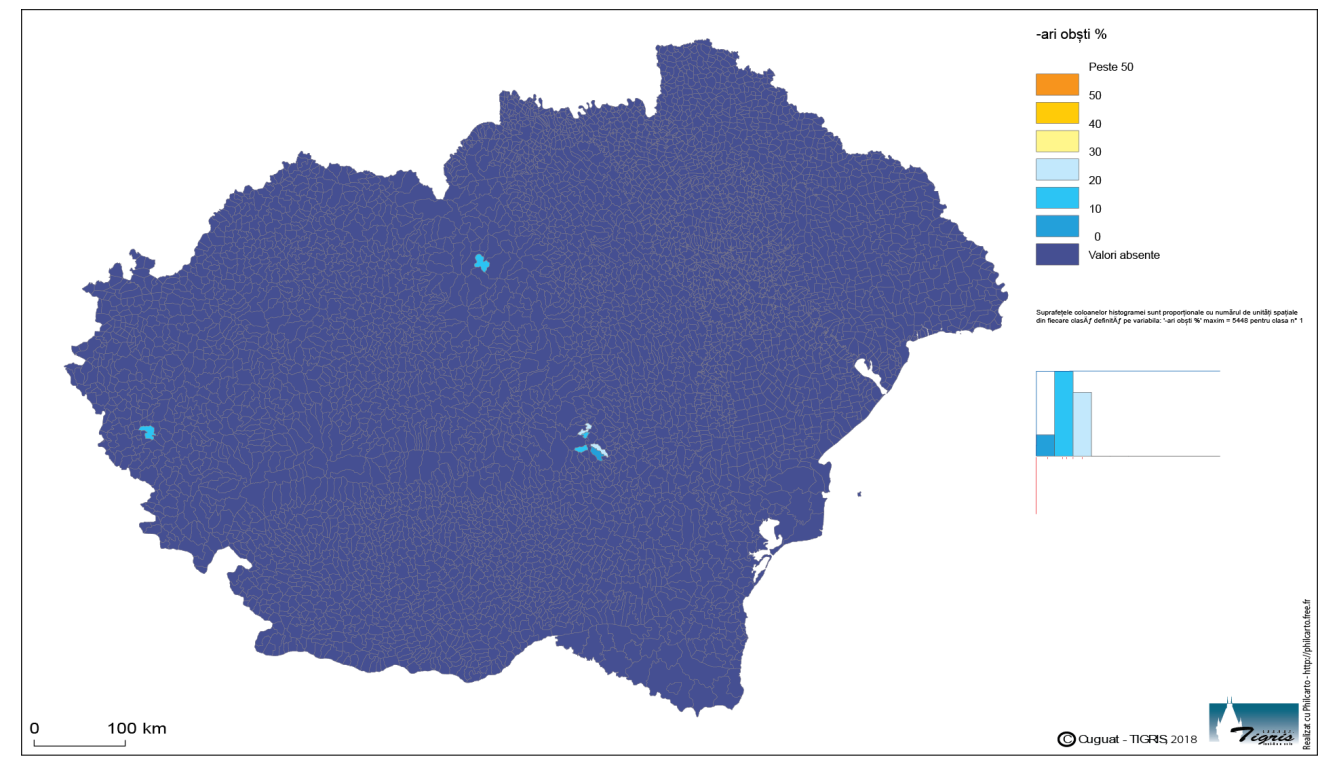

Figura 9: Distribuția oiconimelor cu sufixul - ari ce arată dezvoltarea localităților din comunități de țărani liberi în spațiul românesc la nivel comunal.

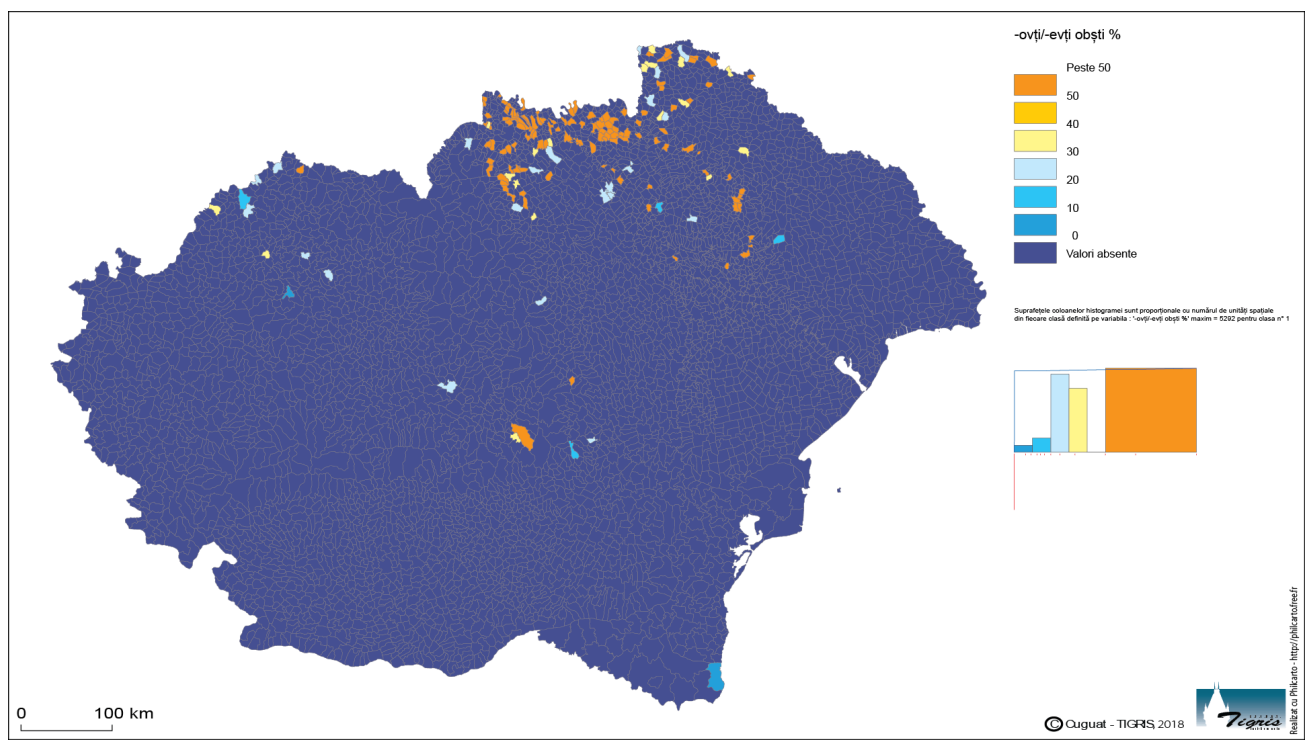

Figura 10: Distribuția oiconimelor cu sufixul -ovți/-evți ce arată dezvoltarea localităților din comunități de țărani liberi în spațiul românesc la nivel comunal.

Sufixul -inţi este chiar mai rar, regăsindu-se în numele a doar 60 de localităţi (0,3\%), cu o localizare spațială și mai izolată, remarcîndu-se, din nou, extremitățile nordice ale Bucovinei, Basarabiei și Transnistriei (Fig. 11), cu o veche și consistentă influență slavă (ucraineană).

Încă o dovadă a vechimii sufixului - ești în română poate fi adusă, dacă analizăm perechea sa de singular -escu, frecvent folosită pentru crearea de patronime, folosite în prezent ca nume de familie. Fără a avea pretenția că lista este exhaustivă, am inventariat peste 100 de asemenea antroponime ${ }^{5}$, realizînd o hartă

\footnotetext{
${ }^{5}$ Este vorba despre următoarele nume: Alexandrescu, Andreescu, Angelescu, Anghelescu, Antonescu, Avrămescu, Basarabescu, Bălănescu, Bărbulescu, Bobescu, Bogdănescu, Brătescu, Bucurescu, Călinescu, Chiriacescu, Chirilescu, Chirițescu, Comănescu, Constantinescu, Cosmescu, Costescu, Costinescu, Cretulescu, Cristescu, Cristodorescu, Daminescu, Dănescu, Dăscălescu, Diaconescu, Dinescu, Dinculescu, Drăgănescu, Drăghicescu, Florescu, Frătescu, Frățilescu, Gabrielescu, Gavrilescu, Georgescu, Ghițescu, Grecescu, Hristescu, Iacobescu, Ianculescu, Ignătescu, Iliescu, Ionescu, Iordăchescu, Irimescu, Istrătescu, Ivănescu, Lăzărescu, Lupescu, Manolescu, Marinescu, Mateescu, Mănescu, Micescu, Miculescu, Mihăescu, Mihăilescu, Mircescu, Mirculescu, Mironescu, Mitrescu, Moisescu, Muşatescu, Muşetescu, Năstăsescu, Nicolaescu, Nicorescu, Niculescu, Nistorescu, Olărescu, Onescu, Oprescu, Paraschivescu,
} 


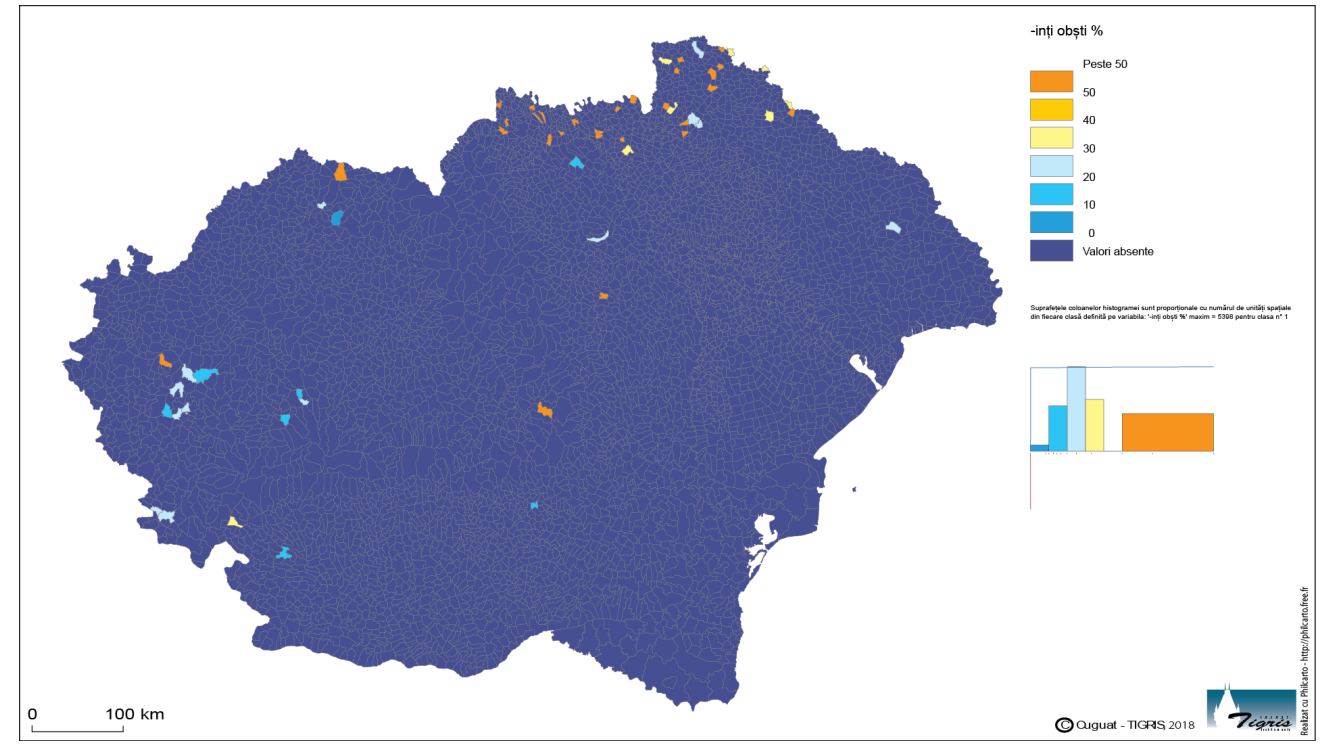

Figura 11: Distribuția oiconimelor cu sufixul -inți ce arată dezvoltarea localităților din comunități de țărani liberi în spațiul românesc la nivel comunal.

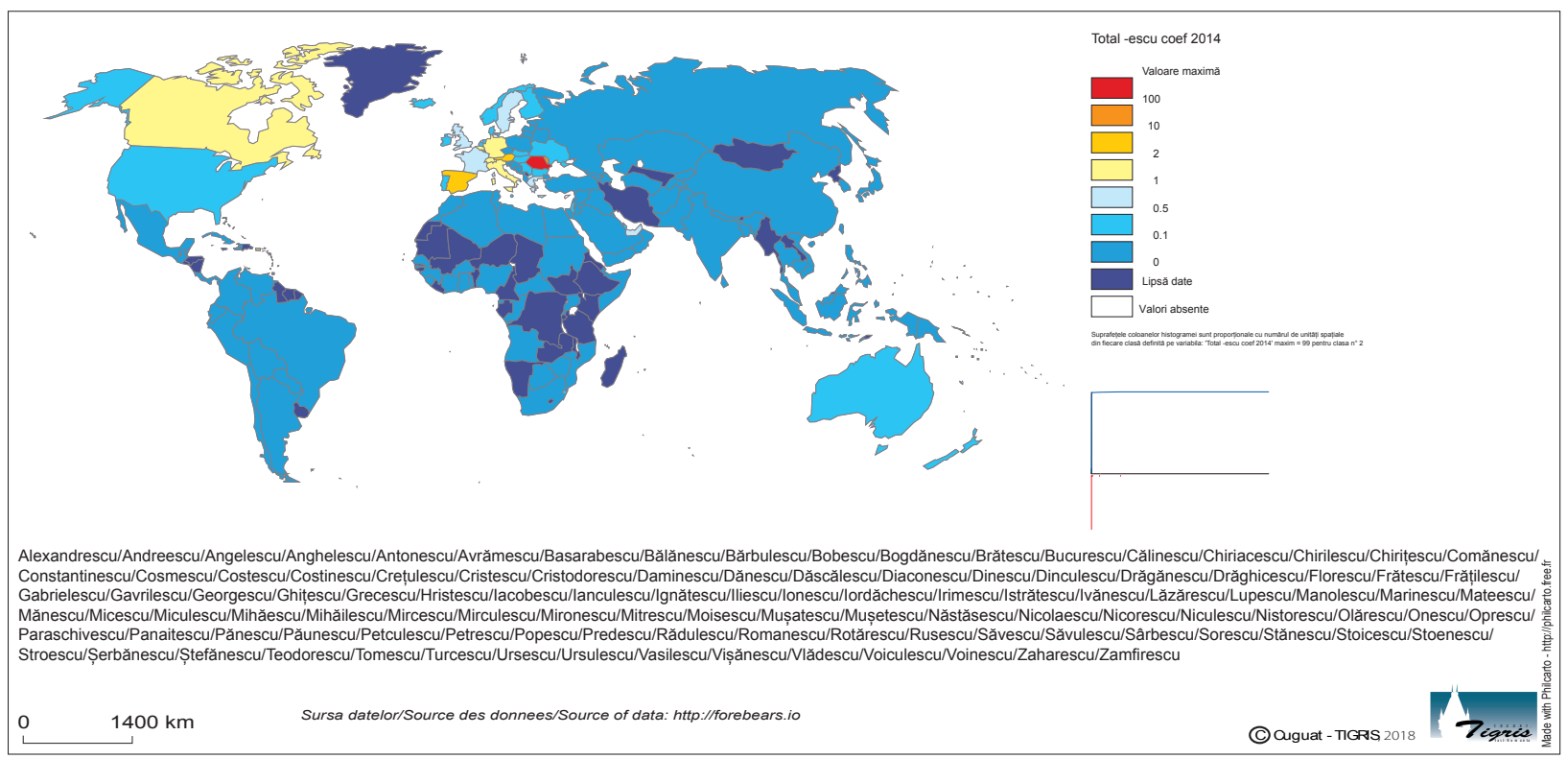

Figura 12: Distribuția purtătorilor numelor cu sufixul -escu (2014). Coeficient de distribuție spațială.

cu distribuția spațială, la nivelul statelor lumii (Fig. 12). Harta este realizată prin metoda coeficienților de distribuție spațială. Dacă analizăm repartiția spațială, țările cu cele mai mari valori ale acestui coeficient sînt România și Republica Moldova, cele două state românofone. De fapt, frecvența cea mai mare se regăsește şi la nivelul fiecărui nume în parte, în majoritatea cazurilor, cea mai ridicată valoare fiind în România, dar, uneori, aceasta se consemnează în Republica Moldova (de pildă, în cazul numelui Micescu). Urmare a „modelului” cultural de migrație românească, în ultimii peste 100 de ani, s-au conturat comunități român(ofon)e în diferite țări, mai ales din Europa (Austria, Germania, Elveția, Italia, Spania, Belgia) și, mai rar, din America de Nord (Canada).

Panaitescu, Pănescu, Păunescu, Petculescu, Petrescu, Popescu, Predescu, Rădulescu, Romanescu, Rotărescu, Rusescu, Săvescu, Săvulescu, Sìrbescu, Sorescu, Stănescu, Stoicescu, Stoenescu, Stroescu, Șerbănescu, Stefänescu, Teodorescu, Tomescu, Turcescu, Ursescu, Ursulescu, Vasilescu, Vișănescu, Vlădescu, Voiculescu, Voinescu, Zaharescu, Zamfirescu. 


\section{Concluzii}

Putem evidenția următoarele aspecte:

- Distribuția spațială a sufixelor ce arată derivarea multor localități din mari comunități patriarhale, evidențiază amploarea și vechimea obștilor țărănești, proces ce poate fi datat, dacă nu de la finele antichității, cel puțin din primele secole medievale.

- Frecvența cea mai mare a acestor sufixe-preponderent românești, mai rar slave-se regăsește în ținuturile extracarpatice (în primul rînd în Moldova istorică, dar și în Țara Româneascăa), remarcîndu-se unele arii cu frecvență însemnată și în regiunile românești de la vest de Carpaţi.

- Cea mai compactă arie în care se manifestă sufixele slave este în nordul Bucovinei, Basarabiei şi Transnistriei.

- Localizarea cea mai frecventă a sufixului patronimic -escu se constată în cele două state românești, de unde, numeroși cetățeni român(ofon)i au migrat spre diferite țări, mai ales din Europa și, mai rar, din America de Nord.

\section{Bibliografie}

Constantinescu, N.A. (1963). Dicționar onomastic românesc, Editura Academiei, București.

De Wulf, C. (1665-1729). Synodorum Generalium et Provincialium Decreta et Canones, Scholiis, Notis ac Historic, vol. I-XII, Albritius \& Coleti, Venezia.

Delehaye, H. et al. (1940). Propyleum ad Acta Sanctorum Decembris, Saint Michel, Bruxelles.

Le Quien, M. (1740). Oriens christianus in quatuor patriarchatus digestus, in quo exhibentur Ecclesiapatriarcha caterique presules totius Orientis, vol. I-III, Typographia Regia, Paris.

Mansi J.D. (1758-1798). Sacrorum Conciliorum nova et amplissima collectio, vol 1-53, Firenze-Venezia.

Moldovanu, D. (1970). Legile formative ale toponimelor românești cu radical antroponimic. I. Formații de plural, în „Anuar de Lingvistică și Istorie Literară”, XXI, p. 15-47.

Moldovanu, D. (coord.) (2014). Tezaurul Toponimic al României. Moldova, vol. II, partea I, Editura Universității „Alexandru Ioan Cuza”, Iași.

Turcuș, Ș. (coord.) (2011). Antroponimia în Transilvania medievală (secolele XI-XIV). Evaluare statistică, evoluţii, semnificații, vol. I, Editura Mega, Cluj.

Ungureanu, A. \& Boamfă, I. (2006). Toponomastică, SEDCOM Libris, Iași.

ancestry.com, 15.02-29.04.2016

catholic-hierarchy.org, 1.05-25.10.2017

dare.ht.lu.se, 18-21.04, 15-27.10.2017

documentacatholicaomnia.eu, 6-11.04.2017

fing.ac, 22.03-11.04.2017

forebears.io, 15.02-29.04.2016

beiligenlexikon.de, 1-7.05.2017

surnames.behindthename.com, 15.02-29.04.2016 